Fakultas Kedokteran Gigi Universitas Andalas

Jalan Perintis Kemerdekaan No. 77 Padang, Sumatera Barat

Web: adj.fkg.unand.ac.id Email: adj@dent.unand.ac.id

\title{
HUBUNGAN ANTARA KEHILANGAN GIGI DAN KESEHATAN GIGI DENGAN KUALITAS HIDUP LANSIA DI PUSKESMAS LUBUK BUAYA KECAMATAN KOTO TANGAH
}

Rahmat Dwi Putra Perkasa 1, Eni Rahmi 1, Ilmiawati 2

Korespondensi : rahmatdwiputra95@gmail.com Telp: 081267143722

\begin{abstract}
Tooth loss is a problem of dental and oral health that is often found in every individual. The prevalence of tooth loss increases with increasing age in a person, especially in the elderly. Tooth loss causes a decrease in oral function, especially in the function of mastication and physical function in the elderly, which then affects the quality of life. To determine the relationship of tooth loss with quality of life related to oral health in the elderly at Puskesmas Lubuk Buaya Kecamatan Koto Tangah. The research uses observational analytic with a cross sectional study approach to 105 elderly people ( $\geq 60$ years). Data collection was carried out by means of general interviews with respondents followed by oral examinations and lastly an interview was conducted using the Oral Health Impact Profile-14 questionnaire (OHIP-14). Data analysis used in this study is Chi-square statistical test. The elderly population in Kecamatan Koto Tangah had an average of 5-10 tooth loss with the most distribution were posterior tooth loss. As many as 50.5\% of elderly people in Kecamatan Koto Tangah had a good quality of life. The majority of respondents with anterior-posterior tooth loss showed poor quality of life. Chi-square test showed that there was a significant relationship between the number of tooth loss and quality of life related to oral health ( $p<0.001$; $O R=16.127)$ and there was a significant relationship between the location of tooth loss and quality of life related to oral health $(p<0.001 ; O R=9,274)$.
\end{abstract}

Keywords: Tooth loss, Elderly, Oral health, Quality of life

Affiliasi penulis : 1. Departemen Prostodonti Fakultas Kedokteran Gigi universitas Andalas, 2. Departemen Mikrobiologi Fakultas Kedoktean Universitas Andalas

\section{PENDAHULUAN}

Secara umum, Seiring dengan proses penuaan, status kesehatan gigi juga memburuk pada lansia, yang dapat terlihat dari tingginya kehilangan gigi yang dialami oleh lansia. Di Indonesia, sekitar 24\% lansia yang berumur 65 tahun atau lebih mengalami kehilangan gigi ${ }^{1}$. Keadaan dari kehilangan gigi baik sebagian ataupun keseluruhan merupakan indikator dari kesehatan gigi dan mulut $^{2}$. Menurut riset kesehatan dasar, 25,9\% penduduk Indonesia memiliki masalah gigi dan mulut (Riskesdas, 2013). Permasalahan kesehatan gigi dan mulut dapat disebabkan karena buruknya status kesehatan gigi dan mulut, terutama karies dan penyakit periodontal yang merupakan dua penyakit penyebab utama kehilangan gigi $^{3}$

ada beberapa bukti bahwa status kesehatan mulut yang buruk pada lansia akan berdampak pada harga diri dan interaksi sosial mereka yang cendrung memiliki efek negatif pada status kesehatan mulut dan kesejahteraan mereka ${ }^{4}$.Peningkatan gangguan penyakit pada lansia dapat 
Fakultas Kedokteran Gigi Universitas Andalas Jalan Perintis Kemerdekaan No. 77 Padang, Sumatera Barat Web: adj.fkg.unand.ac.id Email: adj@dent.unand.ac.id

menyebabkan perubahan pada kualitas hidup lansia. Yang dimaksud dengan kualitas hidup menurut World Health Organization (WHO) adalah persepsi seseorang dalam konteks budaya dan norma yang sesuai dengan tempat hidup orang tersebut serta berkaitan dengan tujuan, harapan, standar, dan kepedulian selama hidupnya ${ }^{5}$. Menurut MacEntee 2007, kualitas hidup yang berhubungan dengan kesehatan mulut atau oral health-related of life (OHRQoL) untuk mendiskripsikan pengaruh dari kesehatan mulut pada pengalaman pribadi pasien. Gregory dkk. mendefinisikan OHRQoL sebagai interaksi dan siklus antara relevansi dan pengaruh kesehatan mulut pada aktivitas sehari-hari ${ }^{6}$.

Untuk menilai OHRQoL, beberapa instrumen telah dikembangkan selama dekade terakhir. Salah satu instrumen yang paling sering digunakan adalah Oral Health Impact Profile-14 (OHIP14 yang ditemukan oleh Locker dan Slade pada tahun 1994 ${ }^{7}$. Kuisioner OHIP-14 ini sudah digunakan oleh beberapa negara seperti Inggri, Australia, dan Kanada. OHIP bertujuan untuk menggambarkan dampak yang terkait dengan kondisi mulut secara umum yang mencakup tujuh domain, yaitu keterbatasan fungsi, rasa sakit fisik, ketidaknyamanan psikis, ketidak mampuan fisik, ketidak mampuan psikis, ketidak mampuan sosial, serta handicap Menurut penelitian Dahl dkk di NonTrondelag, Norway, bahwa kualitas hidup seseorang salah satunya dipengaruhi oleh jumlah gigi yang tersisa, semakin banyak jumlah gigi yang tersisa, maka skor OHIP-14 menjadi lebih rendah di banding dengan seseorang yang memiliki jumlah gigi lebih sedikit ${ }^{8}$.

Menurut Profil Kesehatan Kota Padang Tahun 2016 jumlah lansia di kecamatan Koto Tangah sebanyak 11.752 jiwa dan menempati jumlah lansia terbanyak di Kota Padang. Di kecamatan Koto Tangah sendiri terdapat 4 Puskesmas yaitu Puskesmas Lubuk Buaya, Puskesmas Anak Air, Puskesmas Ikur Koto, dan Puskesmas Air Dingin. Pada Puskesmas Lubuk Buaya jumlah lansia dan pencabutan gigi terbanyak dibandingkan 3 puskesmas lainya. Jumlah lansia yang tinggal di wilayah Puskesmas Lubuk Buaya sebanyak 6.946 jiwa dengan kasus pencabutan gigi tetap sebanyak 750 termasuk pencabutan gigi tetap pada lansia 466 gigi.

Berdasarkan data-data diatas, dengan demikian peneliti tertarik untuk meneliti suatu permasalahan yaitu hubungan kehilangan gigi dengan kualitas hidup terkait kesehatan gigi dan mulut pada lansia di Puskesmas Lubuk Buaya Kecamatan Koto Tangah Kota Padang.

\section{METODE}


Fakultas Kedokteran Gigi Universitas Andalas Jalan Perintis Kemerdekaan No. 77 Padang, Sumatera Barat Web: adj.fkg.unand.ac.id Email: adj@dent.unand.ac.id

Jenis penelitian yang digunakan adalah analitik observasional dengan pendekatan Cross Sectional Study. Penelitian ini dilakukan untuk menganalisa dan membandingkan variabel yang akan diteliti. Sampel dalam penelitian ini adalah sebagian populasi lansia yang tinggal di wilayah Puskesmas Lubuk Buaya yang sesuai dengan kriteria. Cara pengambilan sampel untuk menentukan jumlah sampel pada masing-masing posyandu lansia dengan menggunakan rumus alokasi proporsional atau probability proportional to size (PPS) dan teknik consecutive sampling (non probability), yaitu semua sampel yang memenuhi kriteria dimasukkan dalam penelitian sampai jumlah sampel diperlukan terpenuhi. Jumlah sampel minimal yang diambil pada penelitian adalah 95 pasang. Dengan penambahan proporsi 10\% pada sampel penelitian sehingga jumlah sampel menjadi 105 orang.

Pengambilan data dilakukan melalui wawancara umum dan mengisi Informed consent kepada responden sehingga didapatkan responden yang sesuai dengan kriteria inklusi, kemudian pemeriksaan gigi dilakukan setelah responden menyetujui untuk menjadi responden penelitian. Penelitian dilanjutkan dengan melakukan wawancara kualitas hidup terkait kesehatan gigi dan mulut pada lansia menggunakan kuisioner OHIP-14 yang dipandu oleh peneliti kepada responden. Data yang diperoleh berupa data kategorik. Dalam penelitian ini digunakan uji Chi Square. Syarat uji Chi Square adalah sel yang memiliki nilai expected kurang dari 5, maksimal 20\% dari jumlah sel. Jika syarat uji Chi Square tidak terpenuhi, maka dilakukan penggabungan sel.

\section{HASIL DAN PEMBAHASAN}

\section{Gambaran Kehilangan Gigi}

Berdasarkan penelitian yang telah dilakukan pada lansia berusia diatas 60 tahun yang tinggal di Kecamatan Koto Tangah, rentang usia terbanyak adalah 60-64 tahun dan mayoritas responden memiliki kehilangan gigi sebanyak 1-10 gigi. Hasil penelitian yang sudah dilakukan sejalan dengan pernyataan Hasil Riset Kesehatan Dasar (RISKESDAS) tahun 2007 bahwa kehilangan gigi pada usia 45-64 tahun adalah 1,8\% dan pada usia 55-64 tahun sebesar 5,9\%, dan pada usia 65 tahun ke atas kehilangan gigi mencapai 17,6\%. Hal ini menunjukkan bahwa seiring bertambahnya usia seseorang, kemungkinan kehilangan gigi juga meningkat.

Kehilangan gigi posterior $(52,4 \%)$ banyak dialami oleh lansia di Kecamatan Koto Tangah, sedangkan kehilangan gigi di anterior dan posterior berkisar 47,6\%. Hal ini dikarenakan gigi posterior sulit untuk dibersihkan dibandingkan gigi anterior. Menurut Nguyen et al. pada penelitiannya tahun 2016 menyatakan bahwa kehilangan gigi posterior lebih sering dari pada gigi anterior. Temuan ini didapatkan karena morfologi permukaan oklusal gigi posterior, yang dengan 
mudah menumpuk plak dan sisa makanan. Selain itu, seringkali sulit bagi para lansia untuk membersihkan mulut pada posisi terakhir lengkung gigi, dan ini dapat meningkatkan risiko karies dan periodontitis, yang menyebabkan gigi tanggal ${ }^{9}$. Karies gigi adalah alasan utama untuk pencabutan gigi pada lansia, dan diet yang mengandung gula tinggi merupakan penyebab utama karies gigi pada semua usia ${ }^{10}$. Menurut Sheiham dan James mayoritas karies pada gigi permanen terjadi pada orang dewasa penelitian Sheiham dan James ini menunjukkan bahwa karies gigi yang diinduksi gula berlangsung sepanjang hidup ${ }^{11}$.

Kehilangan gigi pada lansia dapat dikaitkan dengan faktor fisiologis. Salah satu tanda-tanda penurunan faktor fisiologis adalah melemahnya jaringan penyangga gigi sehingga menyebabkan gigi goyang dan mudah tanggal. Penyebab kehilangan gigi yang dialami oleh responden adalah karies gigi dan penyakit periodontal Menurut penelitian Huttner et al. pada tahun 2009 mengemukakan kehilangan perlekatan pada jaringan periodontal dan tulang alveolar sering terdapat pada populasi lansia. Kehilangan gigi juga dapat dihubungkan dengan tingkat pendidikan, pekerjaan, dan pendapatan dari responden. Dari hasil penelitian mayoritas responden berpendidikan terakhir adalah SMA sebanyak 45,7\%. Rendahnya tingkat pendidikan pada lansia cukup mempengaruhi kesadaran untuk menjaga dan memelihara kesehatan gigi dan mulutnya. Salah satu responden tingkat pendidikan terakhirnya di jenjang S3 tetapi untuk kualitas hidup responden tersebut tergolong buruk. Menurut Siagian masyarakat dengan tingkat pendidikan yang tinggi cenderung mempunyai status ekonomi yang lebih tinggi dibandingkan tingkat pendidikan yang rendah dan memiliki kesadaran untuk memperbaiki kesehatan rongga mulut, menggunakan fasilitas kesehatan gigi dan mulut serta gaya hidup yang lebih baik ${ }^{12}$.

\section{Hubungan Kehilangan Gigi Dengan Kualitas Hidup Terkait Kesehatan Gigi Dan Mulut}

Menurunnya fungsi tubuh sehingga menyebabkan keterbatasan serta mulai bermunculan masalah kesehatan pada lansia akan mempengaruhi kesejahteraan dan kualitas hidupnya. Untuk mengukur kualitas hidup terkait kesehatan gigi dan mulut pada lansia digunakan instrumen Oral Health Impact Profile - 14 (OHIP-14). OHIP-14 terbagi menjadi tujuh dimensi dan masingmasing dimensi terdiri dari dua pertanyaan.

Hasil uji statistik tentang hubungan kehilangan gigi berdasarkan jumlah dengan kualitas hidup terkait kesehatan gigi dan mulut pada lansia menunjukkan bahwa nilai $\mathrm{p}<0,05$, berarti dapat disimpulkan bahwa terdapat hubungan yang bermakna. Walaupun begitu, dari hasil penelitian yang dilakukan didapatkan data bahwa masyarakat lansia di Kecamatan Koto Tangah rata-rata memiliki kualitas hidup baik. Hal ini dikarenakan bahwa pada umumnya masyarakat lansia 
menerima keterbatasan atau kekurangan yang dimilikinya. Mereka menyadari bahwa kehilangan gigi sesuatu yang wajar dialami oleh lansia seiring bertambahnya usia, sehingga umumnya lansia tetap menjalani kehidupannya dengan normal.

Penelitian oleh Kotzer et al. pada tahun 2012 mengemukakan bahwa terdapat perbedaan signifikan antara dampak kesehatan mulut terhadap kehidupan penduduk pra-lansia dan lansia. Peneliti mengemukakan kesehatan mulut pada kelompok pra-lansia lebih besar memberikan dampak pada kehidupannya dibandingkan dengan kelompok lansia walaupun kesehatan mulutnya lebih baik daripada lansia. Hal ini dihubungkan dengan harapan dan pengalaman individu meliputi kehidupan sosial, tingkat pendidikan, dan jenis pekerjaan akan sangat mempengaruhi tingkat kepuasan dan ketidakpuasan terhadap kesehatan mulut mereka ${ }^{13}$.

Hubungan kehilangan gigi berdasarkan lokasi kehilangan gigi dengan kualitas hidup terkait kesehatan gigi dan mulut pada lansia pada hasil uji statistik menunjukkan bahwa nilai $\mathrm{p}$ $<0,05$ dapat disimpulkan bahwa terdapat hubungan yang bermakna. Responden dengan kehilangan gigi anterior posterior berdampak lebih besar terhadap kualitas hidupnya. Terlihat pada hasil penelitian didapatkan bahwa pada responden dengan kehilangan gigi anterior posterior rata-rata mempunyai kualitas hidup yang buruk. Hal ini sejalan dengan penelitian Batista et al. 2014 mengemukakan meskipun dengan jumlah kehilangan gigi yang sama subjek dengan kehilangan gigi termasuk gigi anterior memiliki skor OHIP yang lebih tinggi daripada subjek yang hanya kehilangan pada posterior ${ }^{14}$

Hasil penelitian ini menunjukkan bahwa dampak kehilangan gigi pada kualitas hidup terkait kesehatan gigi dan mulut pada lansia yang banyak ditemui adalah pada dimensi fisik diantaranya kemampuan fungsi dan gejala fisik. Kehilangan gigi anterior atas dan bawah sering kali menyebabkan gangguan fungsi bicara. Prosedur terjadinya suara berawal dari laring, lidah, palatum, dan dibantu oleh gigi geligi sehingga akhirnya terbentuk suara. Labio dental adalah huruf yang diucapkan antara lidah dengan gigi anterior atas, apabila terjadi kehilangan gigi anterior maka huruf v, f, ph tidak dapat terucap dengan baik. Kehilangan gigi mempengaruhi pengucapan huruf konsonan, seperti s, z, x, d, l, j, t, ch, dan sh. Demikian juga pada huruf linguo dental, yaitu huruf yang diucapkan antara lidah dengan gigi depan bawah, misalnya th

Kehilangan gigi dapat mengakibatkan terganggunya proses pengunyahan makanan terutama apabila kehilangan gigi posterior pada kedua rahang atas dan bawah. Responden yang kehilangan gigi posterior bermasalah dalam mengunyah makanan. Pada penelitian ini didapatkan responden yang kehilangan gigi 1-10 gigi rata-rata kadang-kadang mengalami kesulitan saat proses pengunyahan, sedangkan responden yang kehilangan > 10 gigi rata-rata mengaku cukup 
sering merasakan sakit di rongga mulut saat mengunyah karena kehilangan gigi yang dialami. Mayoritas responden pada penelitian ini mengalami kehilangan gigi di posterior. Menurut penelitian Bortoluzzi jumlah gigi tetap juga menurun seiring bertambahnya usia dan jumlah gigi tetap yang sedikit juga dikaitkan dengan gangguan pengunyahan ${ }^{15}$.

Penurunan efisiensi pengunyahan pada lansia biasanya berdampak pada meningkatnya keterbatasan dalam pemilihan makanan. Mereka cenderung memilih makanan yang lunak dan menghindari makanan yang keras dan kesat seperti kacang-kacangan, daging, dan buah-buahan yang merupakan sumber vitamin, mineral, dan protein sehingga nutrisi bagi tubuh menjadi berkurang. Hasil penelitian ini menunjukkan bahwa semakin banyak kehilangan gigi yang dialami responden maka akan semakin berdampak pada tingkat kepuasan responden pada saat memilih makanan. Penelitian ini sejalan dengan penelitian Naik et al. 2011 menyatakan kehilangan gigi menyebabkan keterbatasan pada lansia yang tidak hanya berdampak dari segi nutrisi yang mempengaruhi kesehatan fisik tetapi juga kesehatan mental secara keseluruhan ${ }^{16}$.

Kehilangan gigi pada lansia akan berdampak pada estetika penampilan wajah dan kepribadian, yang mempegaruhi kinerja sosial dan kemampuan individu untuk membentuk hubungan sosial. Dari hasil penelitian Naik et al berbanding terbalik dengan penelitian yang sudah dilakukan. Pada penelitian ini, sebagian besar responden mengaku tetap nyaman, tidak merasa cemas atau khawatir, tidak merasa malu, dan tegang dengan adanya kehilangan gigi. Hal ini disebabkan karena pada lansia seseorang akan menerima apa yang telah terjadi dan merasa hal tersebut sudah pasti terjadi saat bertambahnya usia. Hal ini sejalan dengan penelitian Naik et al. 2011 bahwa cukup banyak subjek penelitian yang membahas kehilangan gigi dengan keluarga dan teman-temannya, yang menunjukkan penerimaan masyarakat terhadap kehilangan gigi sebagai prosedur penuaan normal ${ }^{16}$.

\section{KESIMPULAN}

Berdasarkan hasil penelitian yang telah dilakukan pada penduduk lansia di Kecamatan Koto Tangah, maka dapat diambil kesimpulan sebagai berikut yaitu Lansia di Kecamatan Koto Tangah rata-rata kehilangan gigi terbanyak 1-10 gigi dan distribusi tertinggi adalah kehilangan gigi posterior, kualitas hidup terkait kesehatan gigi dan mulut pada lansia di Kecamatan Koto Tangah tergolong baik, terdapat hubungan yang bermakna antara jumlah kehilangan gigi dengan kualitas hidup terkait kesehatan gigi dan mulut pada lansia $(\mathrm{p}=0,001)$. Responden dengan kehilangan gigi $>10$ berpeluang 16 kali lebih besar untuk memiliki kualitas hidup yang buruk dan terdapat hubungan yang bermakna antara lokasi kehilangan gigi dengan kualitas hidup terkait 
kesehatan gigi dan mulut pada lansia $(\mathrm{p}=0,001)$. Responden dengan kehilangan gigi anterior dan posterior berpeluang 9 kali lebih besar untuk memiliki kualitas hidup yang buruk.

\section{KEPUSTAKAAN}

Anwar, Ayub Irmadani. 2014. Hubungan Antara Status Kesehatan Gigi Dengan Kualitas Hidup Pada Manusia Di Kecamatan Malili, Luwu Timur. Dentofasial, Vol.13, No. 3, Oktober 2014: 160-164.

Wijayanti, Wahyu. 2014. Perbedaan Kualitas Hidup Pasien Geriatri Di RSUP DR. Kariadi Semarang Yang Mendapat Perawatan Gigi Dan Tidak Mendapat Perawatan Gigi. Program Pendidikan Sarjana Kedokteran Fakultas Kedokteran Universitas Diponegoro. Semarang.

Saintrain, Mmaria Vieira de., Eliane Helina Alvim de Sauza. 2010. Impact of Tooth Losson The Quality of Life. Ooriginal Article: Gerodontology, 2012:29, e632-e636.

Montoya., José Antonio Gil., Ana Lucia Ferreira de Mello, dkk. 2015. Oral Health in Elderly Patients and Its Impact on General Well-Being: A Nonsystematic Review. Clinical Interventions in Aging, 2015:10, 461467

Wangsahardja, Kartika., Olly V. Dharmawan., dan Eddy Kasim. 2007. Hubungan Antara Status Kesehatan Mulut Dan Kualitas Hidup Pada Lanjut Usia. Universa Medicina, Vol. 26, No. 4, Oktober-Desember 2007.

Amurwaningsih, Musri., Uswatun Nisaa., Arum Darjono. Analisis Hubungan Kualitas Hidup Yang Berhubungan Dengan Kualitas Hidup (OHRQoL) Dan Status Kecemasan Dengan Status Nutrisi Pada Masyarakat Usia Lanjut. Fakultas Kedokteran Gigi Unissula. Semarang.

Jain, M., et al. 2012. How Do Age and Tooth Loss Affect Oral Health Impacts and Quality of Life? A Study Comparing Two States of Gujarat and Rajasthan. Journal of Dentistry, Tehran University of Medical Sciences, 2012; Vol. 9, No. 2.

Anwar, Ayub Irmadani. 2014. Hubungan Antara Status Kesehatan Gigi Dengan Kualitas Hidup Pada Manusia Di Kecamatan Malili, Luwu Timur. Dentofasial, Vol.13, No. 3, Oktober 2014: 160-164.

Nguyen Minh Son., Ulle Voog-Oras., Trilin Jagomagi., Toai Nguyen., Jana Olak., Mare Saag. 2016. Tooth Loss and Risk Factors Among Elderly Vietnamese. Stoma Edu J. 2016;3 (2);126-131.

Tiwari Tamanna., Sharon Scarbro., Lucinda L. Bryant., Jini Puma. 2017. Factors Associated with Tooth Loss in Older Adults in Rural Colorado. J Community Health, June 2016, 41(3): 476-481.

Sheiham A., W.P.T. James. 2015. Diet and Dental Caries: The Pivotal Role of Free Sugars Reemphasized. Journal of Dental Research, September 2015, 1-7.

Siagian, Krista V. 2016. Kehilangan Gigi Pada Rongga Mulut. Jurnal e-Clinic (eCL). Vol. 4. No.1. Januari-Juni 2016.

Kotzer, R. D., et al. 2012. Oral Health Related Quality of Life in an Aging Canadian Population. Health and Quality of Life Outcomes Journal.

Batista Marilia Jesus., Herenia Procopio Lawrence., Maria da Luz Rosario de Sousa. 2014. Impact of Tooth Loss Related to Number and Position on Oral Health Quality of Life Among Adults. Health and Quality of Life Outcomes, 2014, 12:165.

Bortoluzzi, Marcello Ccarlos., Jefferson Traebert., Renata Lasta., Thalany Naila da Rosa., Diogo Lenzi Capela., Andréia Antoniuk Presta. 2012. Tooth Loss, Chewing Ability and Quality of Life. Contemporary Clinical Dentistry, Oct-Dec 2012, Vol. 3, Issue. 4.

Naik Amit Vianayak., Ranjana C. Pal. 2011. Study of Emotional Effect Of Tooth Loss in an Aging North Indian Community. International Scholarly Research Network, volume 2011, 4 pages. 